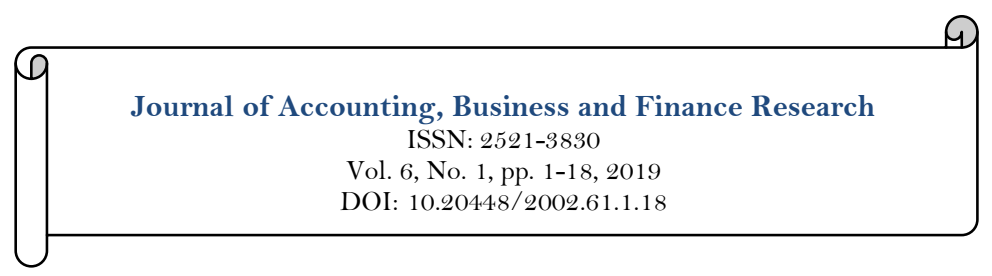

\title{
Review of Theoretical Explanations of IPO Underpricing
}

\author{
Fouad Jamaani ${ }^{1 *}$ \\ Manal Alidarous ${ }^{2}$ \\ 'School of Economics, Finance, and Marketing, College of Business, RMIT University, Melbourne, VIC. 300O, Australia \\ Department of Accounting, College of Business Administration, Taif University, Saudi Arabia \\ Email:ohuepaulitua@yahoo.com
}

\begin{tabular}{|c|c|}
\hline Abstract & \\
\hline $\begin{array}{l}\text { Motivated by a lack of availability of theoretical review of Initial Public } \\
\text { Offerings (IPO) underpricing, this paper recognized a lack of presentation } \\
\text { of theoretical explanations of the phenomenon of IPO underpricing in the } \\
\text { literature. This makes scholars and investors interested in IPO underpricing } \\
\text { research to face difficulty when it comes to the decision to employ IPO } \\
\text { underpricing models. Hence, this paper provides a concise but comparatively } \\
\text { adequate review of competing IPO underpricing theories. This review } \\
\text { covered } 13 \text { theoretical models based on information asymmetry, institutional } \\
\text { explanations, ownership and control reasons, and behavioral explanations to } \\
\text { elucidate the phenomenon of IPO underpricing. Based on this review, the } \\
\text { authors found that the underpricing phenomenon is eventually elucidated by } \\
\text { the existence of information asymmetry amongst key IPO parties including } \\
\text { the issuing firm, the underwriter, and the investor. Across the } 13 \text { reviewed } \\
\text { IPO underpricing theories, the Entrepreneurial Wealth Losses (EWL) } \\
\text { theory emerges as a compelling asymmetric information model. This is } \\
\text { because it solves the problem of information asymmetry between the issuer } \\
\text { and investor while accounting for the endogenous relationship between } \\
\text { underwriter reputation and IPO underpricing. }\end{array}$ & $\begin{array}{l}\text { Keywords: } \\
\text { Initial public offering } \\
\text { Underpricing } \\
\text { Underwriter reputation } \\
\text { Endogeneity } \\
\text { And theories. } \\
\text { JEL Classification: } \\
\text { G14; P51; G24; C18. } \\
\text { Licensed: } \\
\text { This work is licensed under a } \\
\text { Creative Commons Attribution } 4.0 \\
\text { License. } \\
\text { Publisher: } \\
\text { Scientific Publishing Institute }\end{array}$ \\
\hline
\end{tabular}

Funding: The authors are grateful to the generous financial support provided by the Ministry of Education in Saudi Arabia and Taif University in Saudi Arabia.

Competing Interests: The authors declare that they have no competing interests.

Acknowledgement: This paper has benefited from careful readings and helpful suggestions from Professor Michael

Dempsey and Dr. Michael Gangemi.

\section{Introduction}

Surprisingly, only a comparatively small number of corporate events have garnered much attention from scholars, the business world, media, and the general public when compared to initial public offerings (IPOs). The general focus is on the high and occasionally remarkable first-day immediate returns that the share prices of newly listed firms record. Recently, Ritter (2008) indicates that 108 IPO firms floated part of their shareholdings in 2017 , so raising total proceeds of US $\$ 24.53$ billion. The money left on the table by these United States (U.S.) IPO issuers accounted for US\$3.69 billion, attracting an average underpricing level of $15 \%$. The IPO underpricing phenomenon is reported not only in the developed equity markets such as the U.S. but is also recognized in virtually in every stock market around the globe. In an annually updated report in January 9, 2018, Loughran, Ritter, and Rydqvist (1994) document average, country-level underpricing ranging from $3.3 \%$ to $270.1 \%$ across 54 nations over the last three decades. It is not fully understood why entrepreneur founders across countries sell their own shares to initial IPO investors at large discount, an act that constitutes a considerable cost of going public (Liu \& Ritter, 2011). In fact, what is puzzling is trying to understand the willingness of IPO owners across countries to give away part of their firms very cheaply, particularly given the existence of substantial heterogeneity in underpricing across national economies, 
specifically within industrial and emerging nations. In Loughran et al. (1994) report, average underpricing for advanced countries such as Japan, the United Kingdom, and Denmark is recorded as being 44.7\%, 7.4\%, and 25.9\%, respectively, while similar figures for developing nations of Saudi Arabia, Argentina, and Pakistan are $239.8 \%, 4.2 \%$, and $22.1 \%$, also respectively. What makes average underpricing to be as low as $4.2 \%$ and as high as 239.8\% in emerging economies such as Argentina and Saudi Arabia. Also what makes average underpricing figures to be as high as $44.7 \%$ and as low as $7.4 \%$ in Japan and Denmark, respectively, these countries being advanced economies.

The critical question is what theoretical model and determining factors can explain such puzzling variations in underpricing across global IPO markets?. This has inspired the emergence of a large theoretical literature in the last four decades pursuing rational explanations as to why IPOs are underpriced differently across countries. As shown below in Figure 1, Jenkinson and Ljungqvist (2001), Loughran and Ritter (2002), Ritters and Welch (2002), Daily, Certo, Dalton, and Roengpitya (2003), Kennedy, Sivakumar, and Vetzal (2006), Ljungqvist (2007) and Fitza and Dean (2016) have reviewed various IPO underpricing theories based on information asymmetry, institutional explanations, ownership and control reasons, and behavioral explanations.

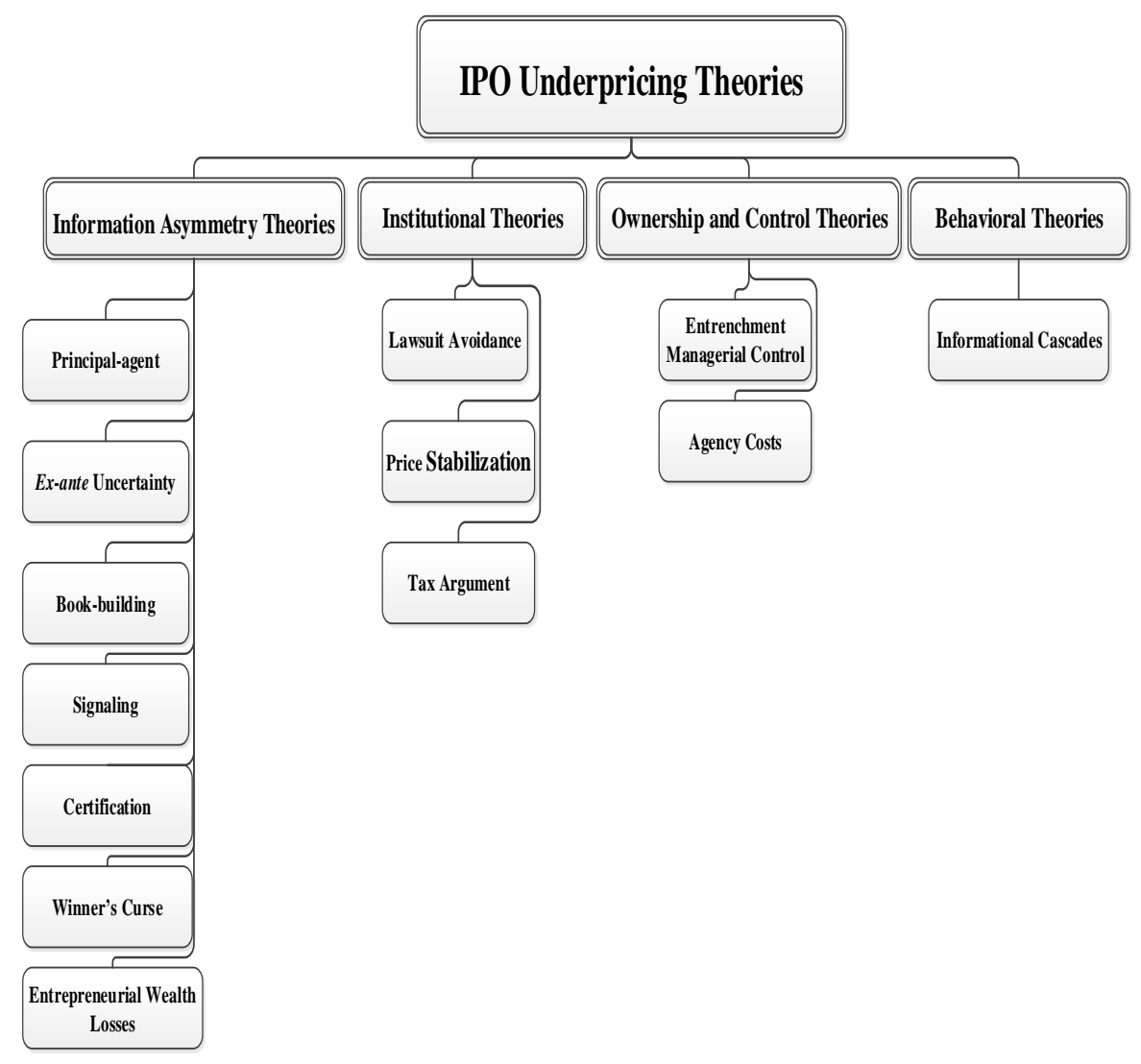

Figure-1. Dominant IPO Underpricing Theories.

The problem is that the availability of a systemic review that presents a variety of IPO underpricing theories at once is absent in the literature. Consequently, this makes it difficult for researchers and investors to understand the relationship between those models in comprehending the phenomenon of IPO underpricing. For this reason, this paper is motivated to provide a brief but comprehensive review of a number of underpricing theories discussed in the literature. This paper is organized into seven sections. Section 2 presents a brief discussion of why IPO companies decide to go public while Section 3 also presents the key IPO parties in order to understand the mechanism of information asymmetry in the IPO market. Section 4 provides a discussion of seven competing asymmetric information models. Section 5 renders a presentation of four theories based on institutional explanations while Section 6 presents two models based on ownership and control reasons. Section 7 provides one theoretical model based on behavioral explanations. Section 8 concludes this paper.

\section{Why Do Firms Go Public?}

The decision to go public marks a significant landmark in the life of un-listed or private firms. The interesting question is why a privately owned company decides to go public. There are three main reasons explaining why a firm decides to list its shares on a stock market as shown in Figure 2. Firstly, by going 
public, a firm's owners can sell part of their shareholdings in the company in exchange for cash, enabling them to utilize the proceeds of the sale for other expenditures or to diversify their investments (Loughran \& Ritter, 2002). Secondly, by going public, a firm can access public equity capital to obtain less expensive funding for new investment plans, finance further business expansion, and repay outstanding loans (Ljungqvist, 2007). That is, when a private firm reaches a stage where the financial capacity of the current shareholders is limited, and cannot finance further growth plans, entering the equity market provides an alternative financing choice. Thirdly, by going public, firms can reap other indirect benefits, such as increasing corporate publicity, enhancing the promotion or advertising of the firm's trademarks and products, and attracting a different caliber of skilled employees (Demers \& Lewellen, 2003).

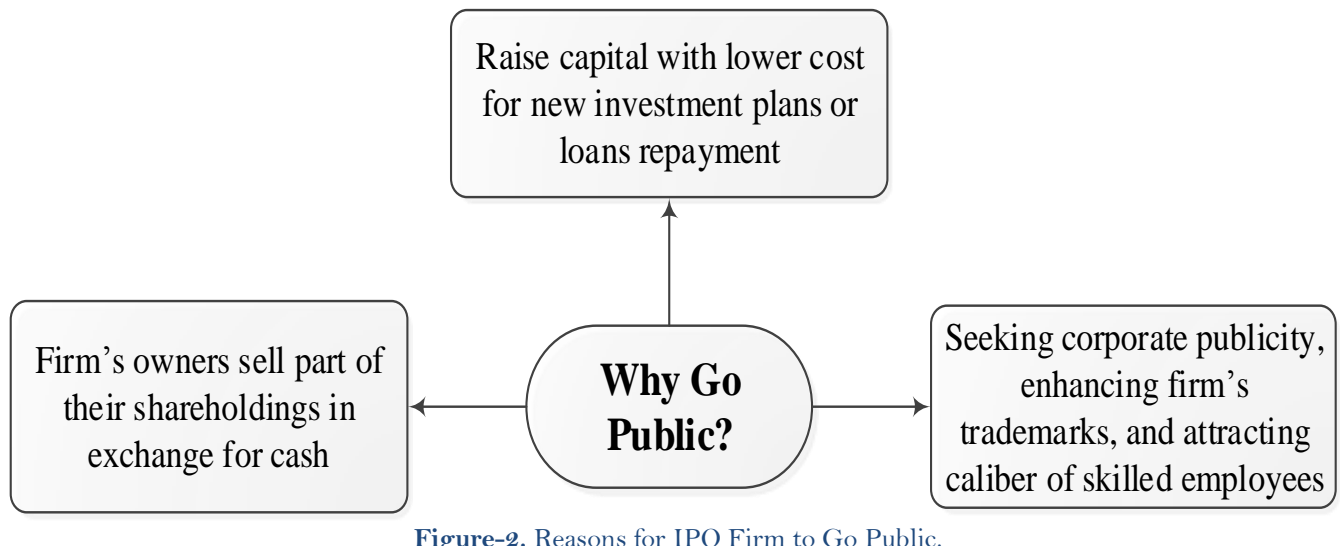

Figure-2. Reasons for IPO Firm to Go Public.

However, as well as certain advantages for going public, there are some disadvantages associated with this decision. For instance, a loss of control by business founders and current shareholders can be an obvious consequence due to public flotation of part of their shareholding (Smart \& Zutter, 2003). That is, as the shareholding base is widened with public flotation, new shareholders gain voting rights that could dilute the voting rights of the founders and current shareholders (Dolvin \& Jordan, 2008). Besides, by going public the management of IPO firms take on additional legal and moral obligations in the form of rigid information transparency and disclosure requirements to act according to the best interests of the larger group of shareholders (Ritterr, 1987). Upon public listing, IPO firms might compromise their competitive advantage by being obligated to increase their information disclosure about current operations and expansion plans as required by security exchange commissions (Habib \& Ljungqvist, 2001).

By going public IPO firms have to bear direct costs of public listing including listing fees, underwriting fees, and brokerage, legal and accounting fees, share registry costs, and also other indirect costs, such as the increased cost of preparing annual financial reports in compliance with disclosure and listing standards and codes (Loughran \& Ritter, 2002). In summary, Jenkinson and Ljungqvist (2001) argue that despite the associated disadvantages of going public, approaching the equity capital market remains an efficient option for firms to provide sustainable financing sources and quick access to liquidate part of their holdings. Since the advantages of going public outweigh the disadvantages, it is imperative to understand the role of key IPO parties. This is discussed in the next section below.

\section{Key IPO Parties}

Ljungqvist (2007) states that three important parties are involved in every IPO. These are the issuing firm, the underwriter, and the investor as shown in Figure 3.

\subsection{The Issuing Firm}

The issuer of an IPO firm is the first important part of the IPO market, and it lists part of its holdings in an existing or newly established company for the first time in a stock market. It does this either through selling existing shares or creating new ones where the former and the latter are secondary and primary share offerings, respectively. The offering could either be one of those two methods or a mixture of the two. The main goal of the issuer is to obtain the highest possible offer price for the floated shares. In general, the issuing firm has the absolute discretion to decide how much it needs to float in compliance with the requirements of every stock exchange authority in every country (Loughran \& Ritter, 2002). IPO literature including Allen and Faulhaber (1989), Grinblatt and Hwang (1989) and Welch (1989) shows that IPO issuers can be classified as high quality and low quality (see Figure 3). They argue that the former own comprehensive private information about the future cash flows of their operations; hence they know exactly the precise present value of their firms while the latter are unsure about the intrinsic value of their companies. The issuer appoints an underwriter to work as an advisory body setting up a suitable offer price and preparing the necessary documentation in compliance with the stock market listing requirements to ensure successful listing. Palmiter 
(1999) and Berglöf and Pajuste (2005) argue that high-quality IPO issuers may be reluctant to disclose the true present value of their firms, fearing the loss of competitive advantage if they communicate positive information related to their future investment opportunities directly to the market. Consequently, Welch (1989) argues that by protecting their market competitive advantage, quality IPO issuers create an asymmetric information problem with IPO investors as shown above in Figure 3. Subsequently, those IPO issuers work to solve this problem by offering underpricing as compensation for IPO investors to differentiate themselves from low-quality IPO issuers.

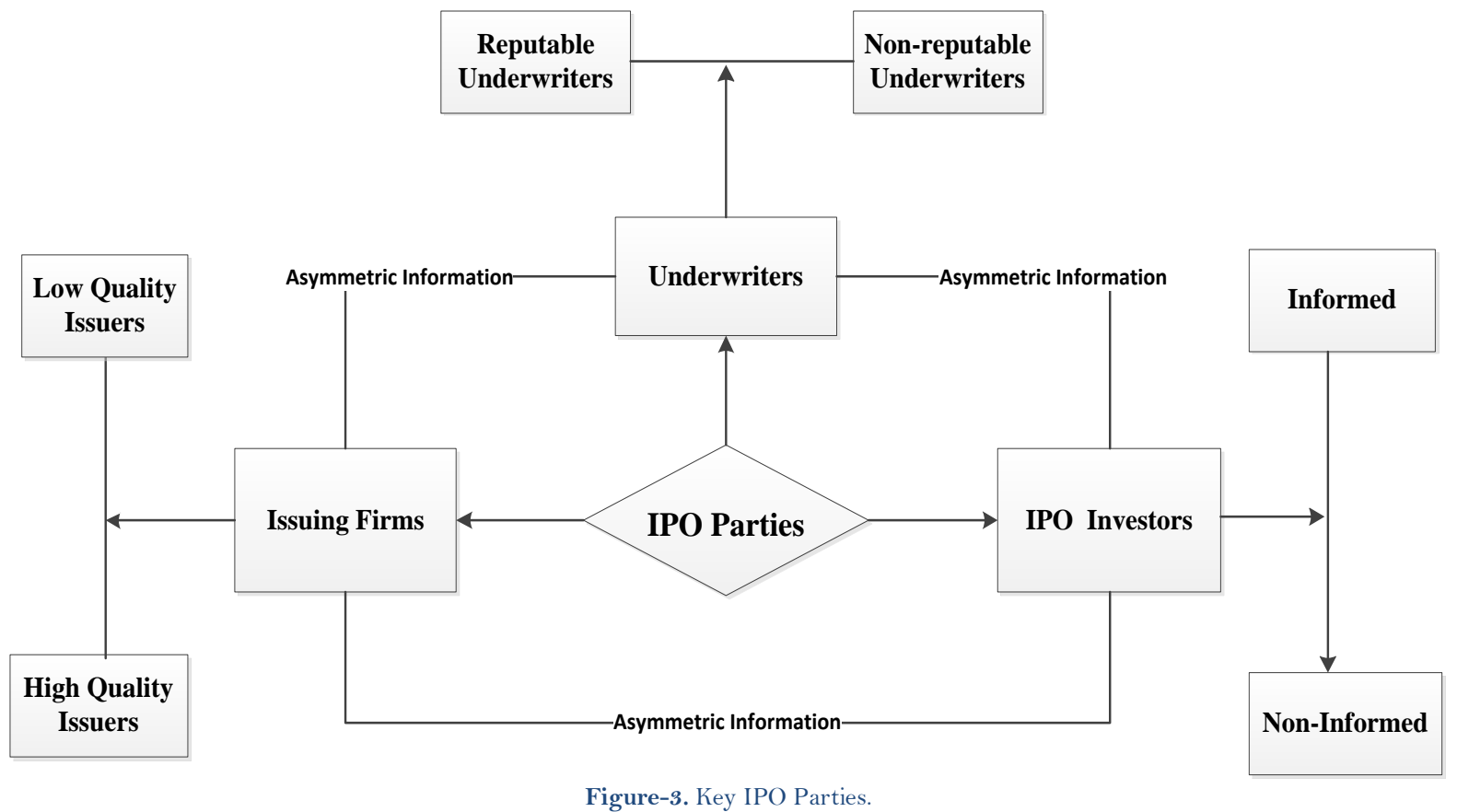

In contrast, Benveniste and Spindt (1989) and Benveniste and Wilhelm (1990) argue that information asymmetry exists between the issuer and the underwriter of the IPO firm when IPO issuers are unsure about the present value of their firms; then they refer the decision to the underwriters in order to determine the present value of their firms. Spatt and Srivastava (1991) show that once the underwriters take over then, they either employ their advisory team to value the IPO firm or solicit the true value of their firms from institutional investors who are financially able to provide an an accurate valuation of the firm. This is done in exchange for receiving a reduced share price of the IPO firm as shown in Figure 3. In this way, the underwriter becomes the second most important party in the IPO market.

\subsection{The Underwriter}

The underwriting bank normally takes the form of a large investment bank or commercial bank that in practice conducts the issuing process on behalf of the issuer. The main function of underwriters is to prepare the IPO firm to go public in exchange for underwriting fees, generally referred to as "underwriting spread" (Chen \& Mohan, 2002). To do so, the underwriters have to buy the floating stake that the issuers decide to sell to the public and then the underwriter resells it back to the public (Chahine, 2008). Hence, underwriters thoroughly evaluate the IPO firms in order to decide the desired offer price and price range that enables the IPO firm to be successfully listed. The level of success of an underwriter largely relies on its financial experience, hence the more IPOs it underwrites, the more it is considered to have a market reputation for successful listing (Kirkulak \& Davis, 2005).

Beatty and Ritter (1986) and Lewellen (2006) argue that underwriters can be classified into reputable and non-reputable underwriters as shown in Figure 3. The former tend to control a large stake in the IPO market, have superior advisory teams, and tend to have established connections with institutional investors including hedge funds, mutual funds, and pension funds. They can subsequently conduct thorough evaluations for IPO firms. Not surprisingly, reputable underwriters are expensive to hire in exchange for the premium service they offer. In contrast, Jones and Swaleheen (2010) contend that non-returnable underwriters tend to have small market presentation, small advisory teams, and limited business connections; they tend to charge cheaper underwriting fees for taking the IPO firm public. Lowry and Shu (2002) argue that underwriters sometimes bear the risk of potentially non-full IPO subscription; hence they buy the IPO company at a discount to compensate for this risk. Carter, Dark, and Singh (1998) argue that underwriters have the incentive to underprice the IPO firm in order to attract more IPO investors, reduce marketing efforts, and avoid non-full 
IPO subscription. Ruud (1993) contends that although IPO issuers may be involved in a restricted number of offerings, underwriters are permanent players in the IPO market. They fear to set a low offer price that could result in upsetting future IPO issuers from taking their firms public at a large discount.

However, Ljungqvist (2007) argues that the asymmetric information problem may exist between underwriters and IPO issuers when the former intentionally underprice the latter for personal gain. Liu and Ritter (2010) contend that some underwriters take advantage of their market knowledge and position for their own benefit by receiving side payments from investors. They want this in exchange for a discount offering or large allocation of IPO stocks, a practice that is known as "spinning". Lowry and Shu (2002) argue that underwriters also fear to set the offer price of IPO firms too high because this could result in upsetting or even being sued by angry IPO investors on the grounds the underwriter overpriced the IPO. Ljungqvist (2007) however, asserts the asymmetric information problem may occur between underwriters and IPO investors when the former deliberately overprice the IPO company, thus benefiting the issuer and themselves at the expense of investors. Now that we understand the role of the issuer and the underwriter, the role of the third part of the IPO party, the investor, is discussed below.

\subsection{The Investor}

The investor of an IPO firm constitutes the third important part of the IPO parties. IPO investors tend to be either short-term or long-term investors of which the latter subscribe to the IPO offering and hold shares for a long investment horizon (Jenkinson \& Ljungqvist, 2001). The former, on the other hand, "flip" shares on the first listing day of the IPO firm seeking a quick return (Ljungqvist, 2007). IPO literature frequently differentiates between two types of IPO investors including retail and institutional investors (Autore, Smart, Boulton, \& Zutter, 2014; Hopp \& Dreher, 2013; Ling \& Ryngaert, 1997). Retail investors tend to be individual or private investors and frequently claimed to have limited financial capacity and in-depth knowledge when it comes to analyzing the IPO prospectus (Chenn \& Kao, 2006; Dorn, 2009).

On the other hand, institutional investors tend to be financially sophisticated and understand the workings of mutual funds, pension funds, investment banks, and hedge funds. They know that these institutions have huge access to large pools of financial resources (Cornelli, Goldreich, \& Ljungqvist, 2006). Sullivan and Unite (2001) and Fitza and Dean (2016) argue that due to their large financial knowledge and capability, institutional investors can be repeat customers to underwriters and they have a mutual interest and business relationship in which both parties hope to maintain. This relationship allows the latter to have informational advantages in terms of accessing private information about IPO firms and receiving higher share allocations compared to retail investors. Acknowledging this information gap between retail and institutional investors, Beatty and Ritter (1986), Rock (1986), Michaely and Shaw (1994) and Brau and Fawcett (2006) argue that retail investors can be seen as non-informed investors compared to institutional investors who can be viewed as informed investors in the IPO market (see Figure 3).

In sum, depending on the status of the IPO issuers, underwriters, and investors, an asymmetric information environment tends to exist between those IPO parties and causes IPO underpricing. In response to the mechanism of this asymmetric information environment between the IPO parties, Jenkinson and Ljungqvist (2001), Kennedy et al. (2006) and Ljungqvist (2007) argue that several information asymmetry theories have been developed to explain the phenomenon of IPO underpricing. Their rationale depends on the nature of the information asymmetry that exists between IPO parties.

\section{Information Asymmetry Theories}

This section presents a number of competing information asymmetry models based on the asymmetric information problem between issuing firms and underwriters, investors and underwriters, issuers and investors, and informed and uninformed investors. These include the Principal-agent, Ex-ante uncertainty, Book-building, Signaling, Winner's Curse, and Certification theories as shown below in Figure 4.

\subsection{Principal-Agent}

Baron and Holmström (1980) and Baron (1982) introduced a "principal-agent" model theorizing the cause of IPOs underpricing as a response to information asymmetry between two IPO parties including IPO issuers and underwriters as shown in Figure 5. The authors argue that the latter underprice the former by employing their superior market knowledge, reducing marketing effort, and benefiting buy-side clients and themselves on account of issuers. 


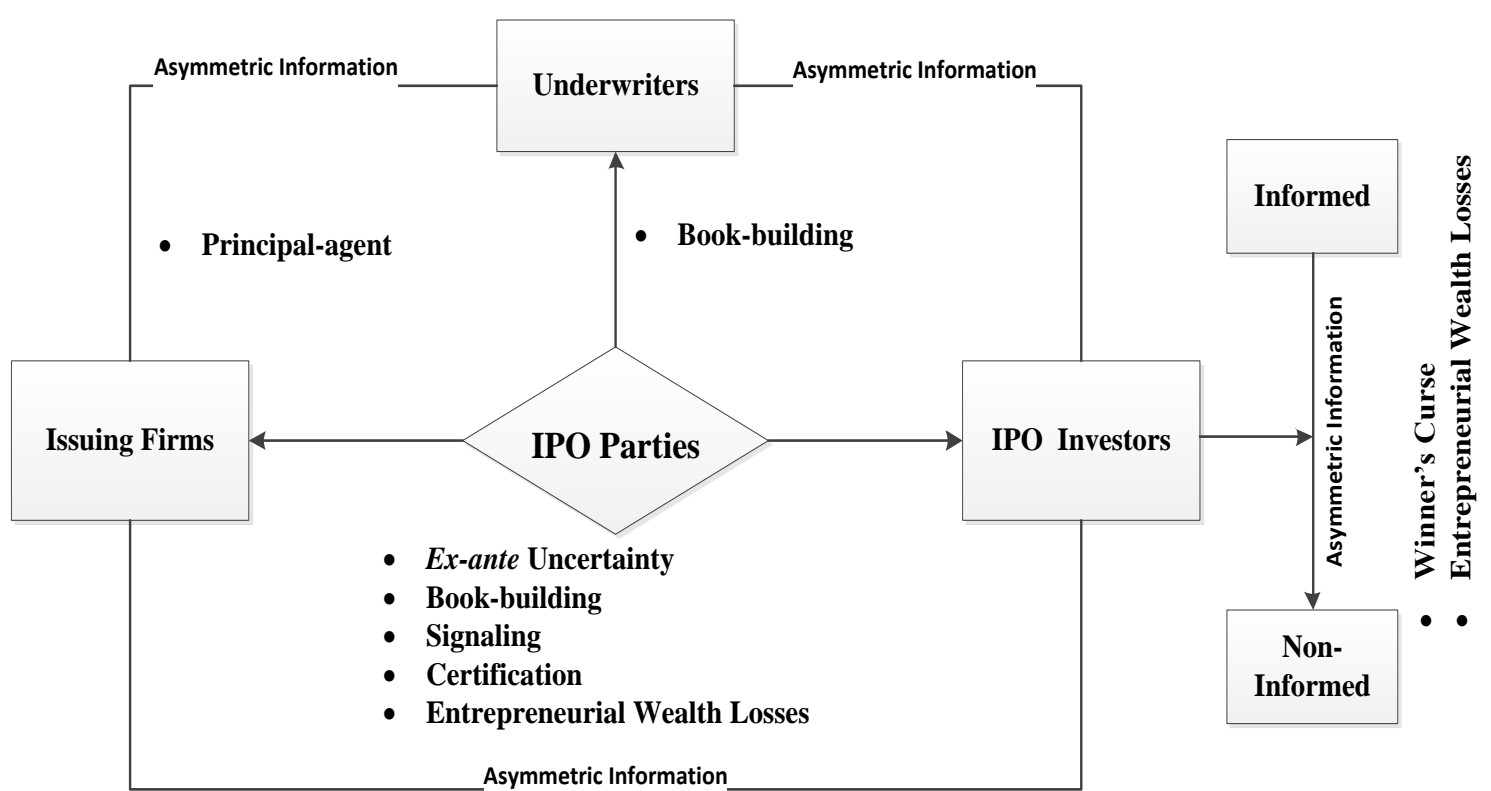

Figure-4. Classification of Information Asymmetry Theories.

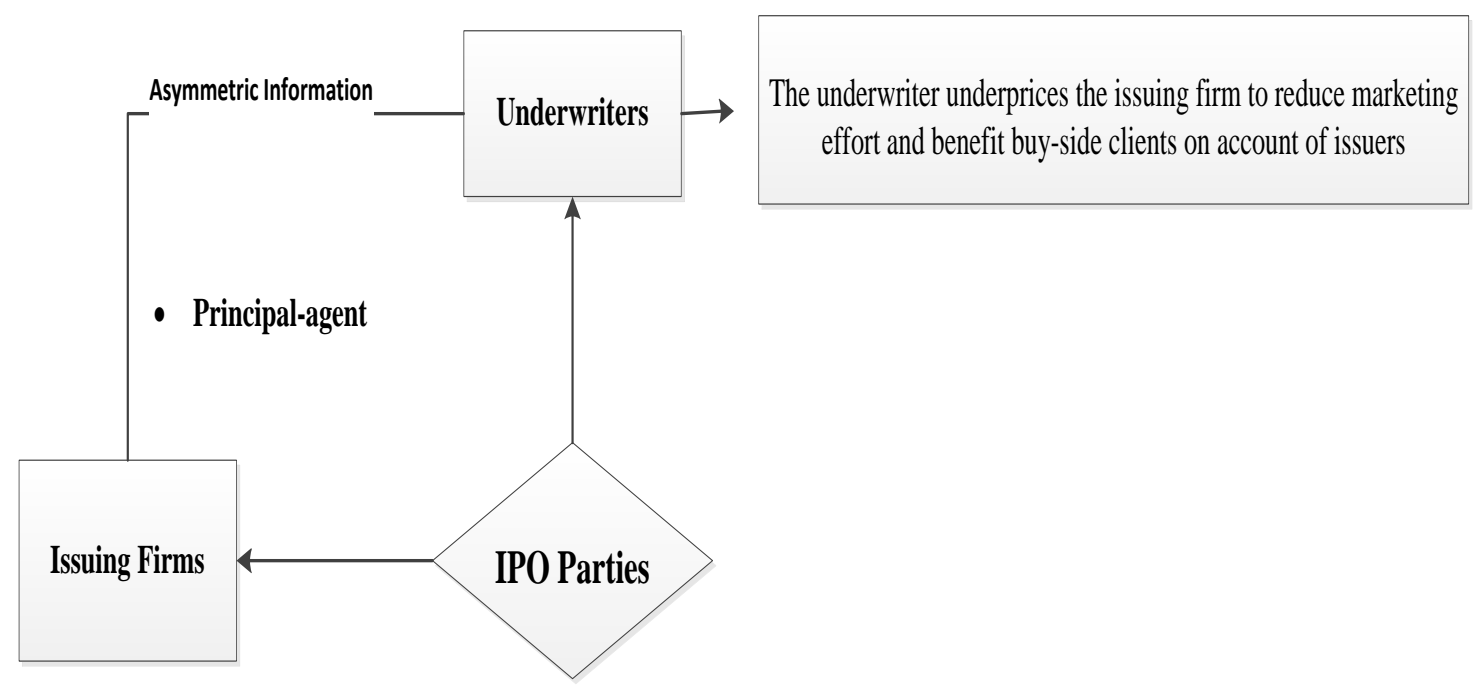

Figure-5. Information Asymmetry Based on Principal-agent Rationale.

Loughran and Ritter (2004) also argue for the presence of a 'dark side' of underwriters by stressing the possibility of agency problems occurring between underwriters and IPO issuers. This could well explain the phenomenon of IPO underpricing. Confirming the presence of the agency problem between IPO issuing firms and their underwriters, Loughran and Ritter (2002) argue that Credit Suisse First Boston was fined $\$ 100$ million in 2002 due to receiving side payments for causing deliberate underpricing of underwritten offerings. Conceptually, Habib and Ljungqvist (2001) argue that the "principal-agent" model can be refuted if underpricing exists for firms underwriting their own offerings since there is no conflict of interest and no asymmetric information to be concerned about. Muscarella and Vetsuypens (1989) examine the "principalagent" model and find no underpricing difference between self-underwritten IPOs and non-self-underwritten IPOs, thus questioning the validity of the principal-agent model. Finally, the principal-agent model only captures the problem of information asymmetry between underwriters and IPO issuers. Yet it is silent on the problem of information asymmetry between investors and underwriters, issuers and investors, and informed and uninformed investors.

\subsection{Ex-Ante Uncertainty}

Beatty and Ritter (1986) argue that underpricing of IPO firms should increase in response to an increase of "ex-ante uncertainty" related to the issuing firm as shown in Figure 6. 


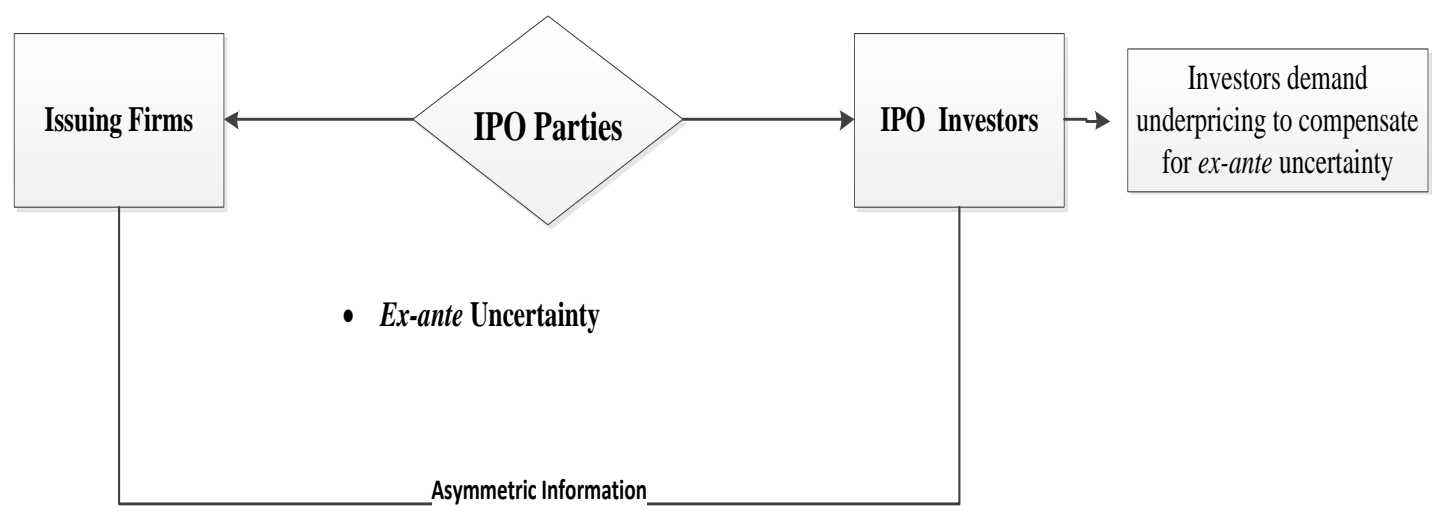

Figure-6. Information Asymmetry Based on Ex-ante Uncertainty Rationale.

Jenkinson and Ljungqvist (2001) demonstrate that ex-ante uncertainty of the issuing firm with investors can, for example, include matters related to the age, size, use of IPO proceeds, and type of IPO firm. Ritter (1984) and Rock (1986) found that the degree of ex-ante uncertainty is a decreasing function of the age of the IPO firm. Engelen and Van Essen (2010) discovered that younger firms create more ex-ante uncertainty about the value of the company; in turn, investors demand higher underpricing for younger companies. Beatty and Ritter (1986) used IPO size to proxy for ex-ante uncertainty, where they empirically documented that larger offerings are normally offered by established firms, while smaller offerings are offered by speculative firms, naming this phenomenon "empirical regularity". Banerjee, Dai, and Shrestha (2011) and Autore et al. (2014) empirically documented the presence of a negative association between the size of the proceeds of IPO firms and the amount of underpricing investors seek to compensate for this risk.

Beatty and Ritter (1986) and Rock (1986) argued that information related to the use of IPO proceeds is useful in reducing ex-ante uncertainty because investors would be better informed about a firm's reasons for going public. Leone, Rock, and Willenborg (2007) found that disclosure of proceeds used for debt repayment purposes, as compared to non-debt repayment uses, increases ex-ante uncertainty regarding the true value of the firm. Prior literature discriminated between two types of IPO firms, i.e. privatization and private companies (Ball, Robin, \& Wu, 2003; Darmadi \& Gunawan, 2013). Privatization company IPOs often involve older firms and well known as relatively government regulated and well established industries, while private firm IPOs tend to be young, small, and relatively unknown (Joness, Megginson, Nash, \& Netter, 1999). Fan, Wong, and Zhang (2007) found that the ex-ante uncertainty of investors is higher for private firm IPOs than for privatized IPOs. Although the "ex-ante uncertainty" hypothesis is empirically supported by Michaely and Shaw (1994), Mok and Hui (1998) and Brau and Fawcett (2006) it cannot explain the substantial underpricing that exists in some countries, particularly in developing markets (Loughran \& Ritter, 2002). Finally, the exante uncertainty only captures the problem of information asymmetry between IPO issuers and investors. It does not capture the problem of information asymmetry between investors and underwriters, issuers and investors, and informed and uninformed investors.

\subsection{Book-Building}

The book-building theories of Benveniste and Spindt (1989), Benveniste and Wilhelm (1990) and Spatt and Srivastava (1991) collectively argue for the presence of asymmetric information between IPO issuers and institutional investors, assuming that institutional investors possess superior information than both underwriters and issuing firms as shown in Figure 7. Hence, the process of book-building reveals valuable information about an issuer by institutional investors. Underwriters compensate truth-telling institutional investors who bid aggressively, in turn, revealing favorable information with larger allocations of shares. 


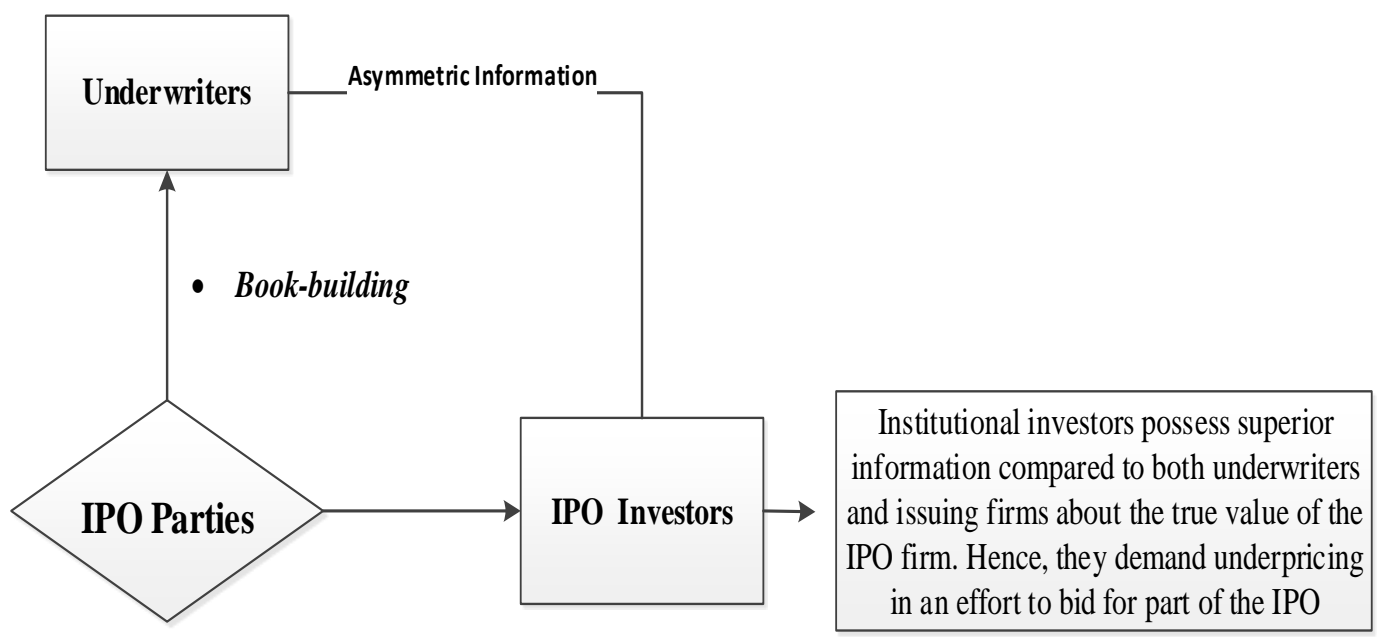

Figure-7. Information Asymmetry Based on Book-building Rationale.

In contrast, underwriters compensate truth-conservative institutional investors who bid conservatively, in turn, revealing no information with smaller allocations of shares. Loughran and Ritter (2002) support the usefulness of the book-building theory for divulging valuation information about the issuer, but argue that the book-building theory only explains a small percentage of IPO discounts. It does not explain the enormous underpricing that occurs in other markets, including developing markets. Brau and Fawcett (2006) survey 336 U.S. chief financial officers (CFOs) to seek their explanations for IPO underpricing and find that CFOs provide little support for the book-building explanation of underpricing. This subsequently leads to questioning the validity of the model in explaining underpricing across countries.

Degeorge, Derrien, and Womack (2007) argue that the book-building model used to be popular during the 1990 s when IPO issuers had the option to choose between different selling methods including auctioning, fixed offer, book-building best offer, and book-building firm commitment. For example, in France in the 1990s, for example, Degeorge et al. (2007) show that the IPO market was approximately divided between auctioned and book-built IPOs, while during the 2000 s the auctions method becomes virtually extinct. In Japan, Kutsuna and Smith (2003) show that auctions rapidly disappeared after book-building was introduced in the Japanese IPO market. Ljungqvists, Jenkinson, and Wilhelm (2003) also document that nearly all countries' preexisting IPO pricing mechanisms have vanished or lost significant market share when book-building entered the scene. Finally, the book-building model only captures the problem of information asymmetry between IPO issuers and investors and investors and underwriters. As well, the model does not capture the problem of information asymmetry between: firstly, issuers and investors; and secondly, informed and uninformed investors.

\subsection{Signaling}

The signaling models 1 of Allen and Faulhaber (1989), Grinblatt and Hwang (1989) and Welch (1989) mutually assert that IPO firms' motivation to underprice is to "leave a good taste in investors' mouths", where these models infer that IPO firms possess private information related to their future cash flows and are aware of their present value, with such private information not made available to investors. Hence, the asymmetric information problem exists between the issuers and investors requiring issuers to offer their firms at a discount to investors as shown in Figure 8.

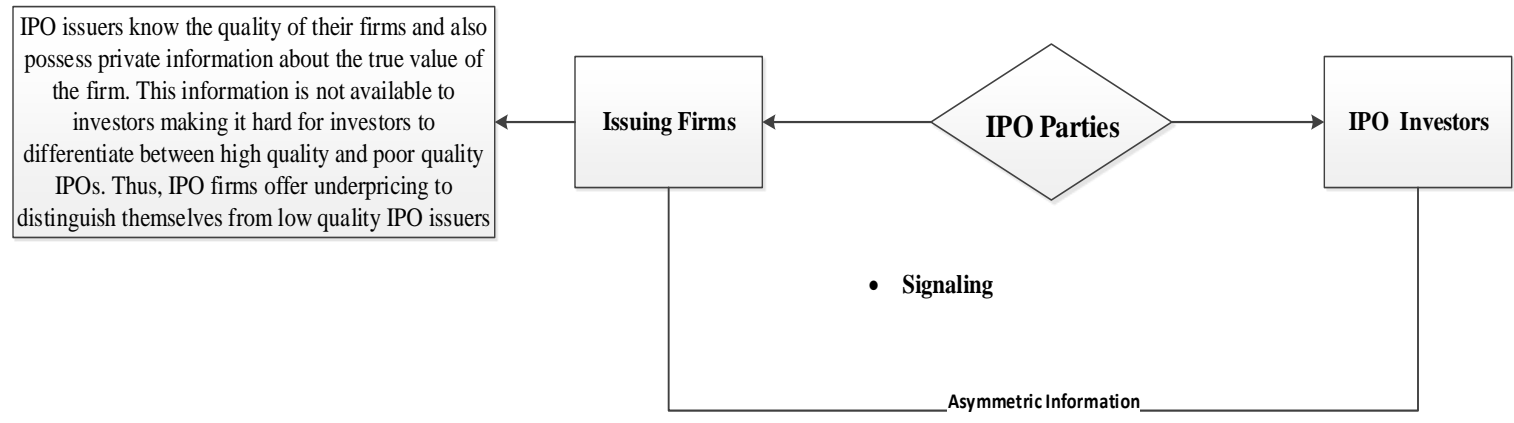

Figure-8. Information Asymmetry Based on Signaling Rationale.

1 Both Allen and Faulhaber (1989) and Welch (1989) employ underpricing as a quality "signal”, while Grinblatt and Hwang (1989) employ both underpricing and ownership retention rate as a quality "signal". 
The intuition behind these signaling models is that low quality issuers will be unwilling to tolerate the cost of the signal in order to mimic high quality issuers, meaning that after an IPO takes place the type of issuer is revealed exogenously (Ljungqvist, 2007). By bearing the high cost of the signal, high quality issuers are expected to make subsequent aftermarket decisions, including issuing seasoned equity offerings (SEOs), which should be received favorably by investors. This will enable them to recoup their losses from underpricing by an increase in the firm's market value (Jenkinson \& Ljungqvist, 2001). Opposed to the premise of "signaling" models, Spiess and Pettway (1997); Gale and Stiglitz (1989), Garfinkel (1993), Leleux and Muzyka (1997), Espenlaub and Tonks (1998), and Kennedy et al. (2006) provide empirical evidence that IPO companies do not recover underpricing costs after their first seasoned equity offering.

The practicality of "signaling" models is also questioned by Ritter (2011) who describes them as "silly academic theories", arguing that "it is unclear why underpricing is a more efficient signal than, say, committing to spend money on charitable donations or advertising". Finally, the signalling model only captures the problem of information asymmetry between IPO issuers and investors while the model does not offer a remedy to the problem of information asymmetry between issuing firms and underwriters, investors and underwriters, and informed and uninformed investors.

\subsection{Winner's Curse}

Rock (1986) introduces the "winner's curse” hypothesis in response to asymmetric information between uninformed and informed investors, asserting that neither the issuer nor the underwriter are well informed compared to institutional investors, who are better informed about the true value of an IPO firm as shown in Figure 9.

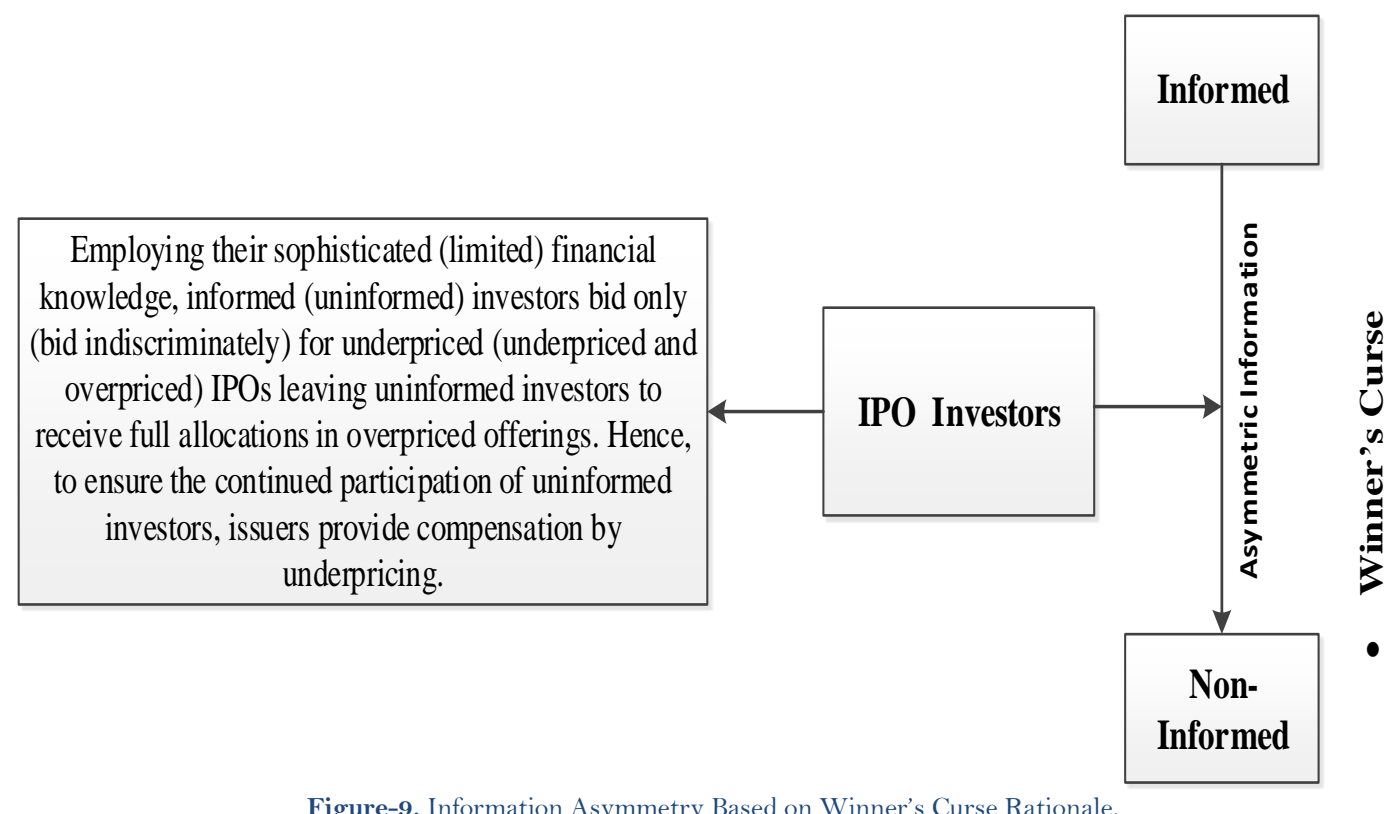

The author argues that institutional investors are indeed informed investors because they can employ their sophisticated financial knowledge to bid only for underpriced IPOs while uninformed investors employ their limited financial knowledge by biding indiscriminately for underpriced and overpriced IPOs. This information gap between informed and uninformed investors enables the latter to receive full allocations in overpriced offerings and create an "adverse selection" problem. Rock (1986) therefore argues that to ensure the perpetual participation of uninformed investors, issuers must provide compensation to alleviate "adverse selection" by underpricing. The winner's curse argument has enjoyed consistent empirical support as documented by Carters and Manaster (1990), Megginson and Weiss (1991), Michaely and Shaw (1994), Banu (2002) and Brau and Fawcett (2006). It is, however, questioned by Beatty and Welch (1996), Lam and Yap (1998), Loughran and Ritter (2002) and Liu and Ritter (2011) as not having enough power to explain the high degree of underpricing, for instance, in developing markets.

Additionally, Habib and Ljungqvist (2001) state that the winners' curse model assumes that the percentage of uninformed and informed investors are exogenously fixed. They argue that participation of uninformed investors can be determined endogenously by incurring promotion costs in order to reduce the "adverse selection" problem faced by these investors, thus leading to lower underpricing. Finally, the winners' curse model only captures the problem of information asymmetry between informed and uninformed investors. It does not provide an understanding of the problem of information asymmetry between issuing firms and underwriters, investors and underwriters, and IPO issuers and investors. 


\subsection{Certification}

Booth and Smith (1986) develop a model based on the assumption of asymmetric information between insiders who are shareholders and outsiders who are prospective subscribers to new issues as shown in Figure 10. They suggest that issuing firms may be viewed as effectively "leasing" the brand name of an underwriter to certify that the issue price reflects available inside information. Consistent with this, Carters and Manaster (1990) show that the issuer's choice of underwriter reputation is inversely related to underpricing of IPOs.

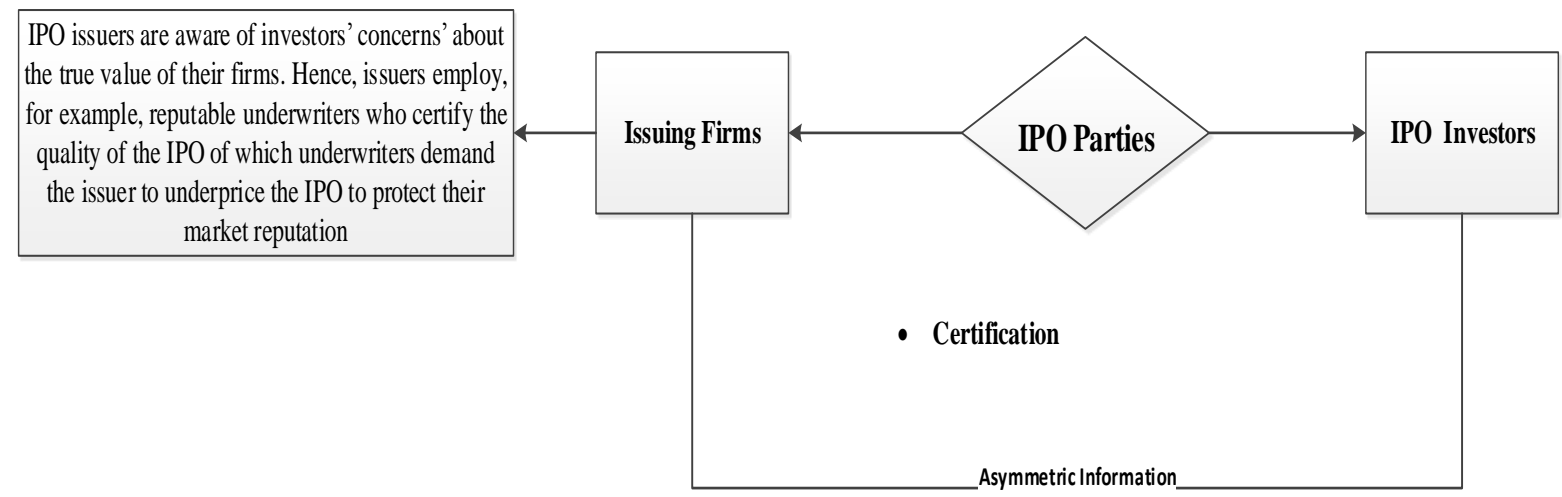

Figure-10. Information Asymmetry Based on Certification Rationale.

Hence, the certification hypothesis argues that underwriters, particularly reputable ones can effectively certify the fair valuation of the offer price of the IPO firm, in turn providing investors with a third party guarantee (Lee, Taylor, \& Walter, 1996). In line with the certification hypothesis, Lees and Wahal (2004) argue that this third party can include certifying the quality of the IPO firm by associating the offering with underwriters, auditors, lawyers, and venture capitalists with established market reputation. The function of this third party is to provide extra quality certification to the issuers in exchange for reducing information asymmetry between the issuing firm and investors. The certification hypothesis receives favorable supporting evidence by Affleck-Graves, Hegde, Miller, and Reilly (1993), Chishty, Hasan, and Smith (1996), Lin (1996) and Hamao, Packer, and Ritter (2000). However, Tomczyk (1996) and Rasheed, Datta, and Chinta (1997) reject it with evidence concerning the prediction of the certification hypothesis.

Marisetty and Subrahmanyam (2010) argue that the certification hypothesis does not provide an adequate explanation of the extreme underpricing in developing countries as most developing IPOs in those countries employ reputable underwriters. Yet they still suffer from large underpricing compared to the underpricing of IPO firms associated with non-reputable underwriters. Finally, the certification hypothesis only captures the problem of information asymmetry between issuers and investors. It does not provide an explanation concerning the problem of information asymmetry between issuing firms and underwriters, investors and underwriters, and informed and uninformed investors.

\subsection{Entrepreneurial Wealth Losses Theory}

Conceptually, as shown in Figure 11, Habib and Ljungqvist (2001) model explains the phenomenon of IPO underpricing by combining the "winners' curse" hypothesis of Rock (1986), the "ex-ante uncertainty" hypothesis of Beatty and Ritter (1986), the "certification" hypothesis of Booth and Smith (1986), and the "signaling” models of Allen and Faulhaber (1989), Grinblatt and Hwang (1989), and Welch (1989).

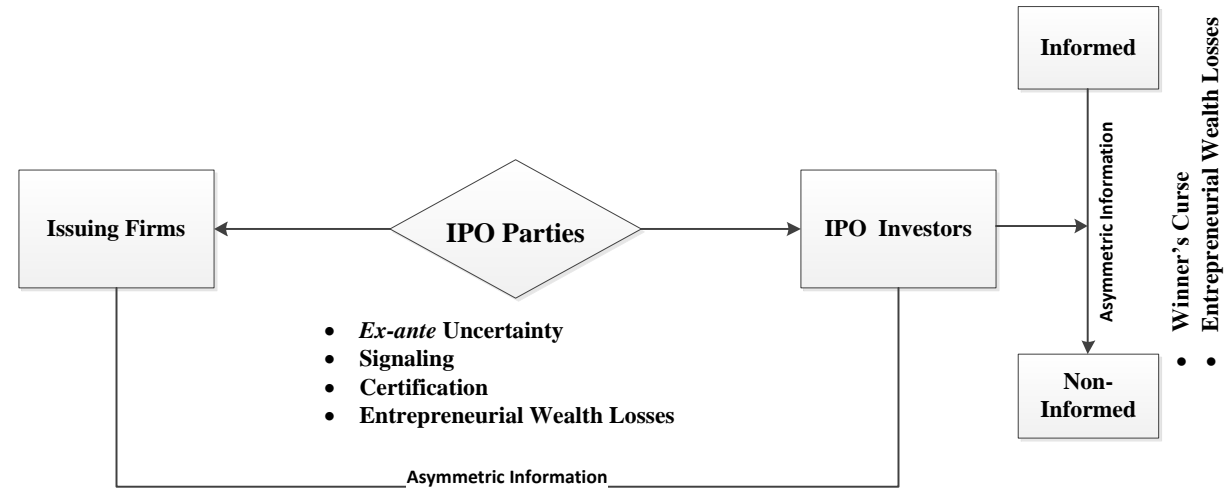

Figure-11. Interaction between the Entrepreneurial Wealth Losses Theory and Other Asymmetric Information Models. 
Habib and Ljungqvist (2001) address the "winners' curse" hypothesis by arguing that participation of uninformed investors can be determined endogenously by incurring more promotion costs. This is achieved, for example, by hiring reputable underwriters to reduce the "adverse selection" problem faced by uninformed investors. This in turn leads to lower underpricing. They also address the "ex-ante uncertainty" hypothesis by arguing that Beatty and Ritter (1986) do not take into account IPO issuers' incentives to alleviate investors' ex-ante uncertainty by increasing promotion costs, for example, employing underwriters with prestigious market reputation. Furthermore they address the "certification" hypothesis of Booth and Smith (1986) arguing that promotion costs can include the employment of a reputable underwriter or prestigious auditor as "certification" signals. These serve to verify the quality of the issuer that was endogenously determined by the issuer when they aim to sell part of their holdings. Habib and Ljungqvist (2001) also address "signaling" models by arguing that when IPO issuers reduce their ownership retention rate and bear the cost of promotion activities such as employing a reputable underwriter, prestigious auditor, or providing voluntary disclosure, promotion activities can serve as substitutes to underpricing.

Habib and Ljungqvist (2001) revolutionized the IPO underpricing literature by providing the first theoretical and empirical evidence for the existence of the endogeneity problem between the key IPO parties. The authors assert that the issuers of IPO firms do not randomly select underwriters, and neither do underwriters randomly agree to underwrite IPO firms. Therefore, the decision to select an underwriter by the issuer is predetermined and it is likely to be based on their decision, at least in part, on the amount of underpricing they anticipate will occur. Consequently, this results in endogeneity bias when regressing underpricing on the choice of underwriter. Habib and Ljungqvist (2001) model has two main premises and they are as follows:

The first is that IPO owners care about underpricing, they are willing to stand to lose from it, and any such losses are proportionally conditional on the number of primary and secondary shares being sold.

The second is that IPO owners can influence the degree of underpricing by promoting their offerings.

The EWL theory emphasizes that neglecting the endogeneity in IPO issuers' incentives to discourage information asymmetry, in turn, reduces underpricing results in the omitted variable bias and leads to biased inferences from empirical work. Based on this rationale, the EWL model provides two separately testable models to explain factors affecting wealth losses and underpricing of IPO issuers as shown below in Figure 12.

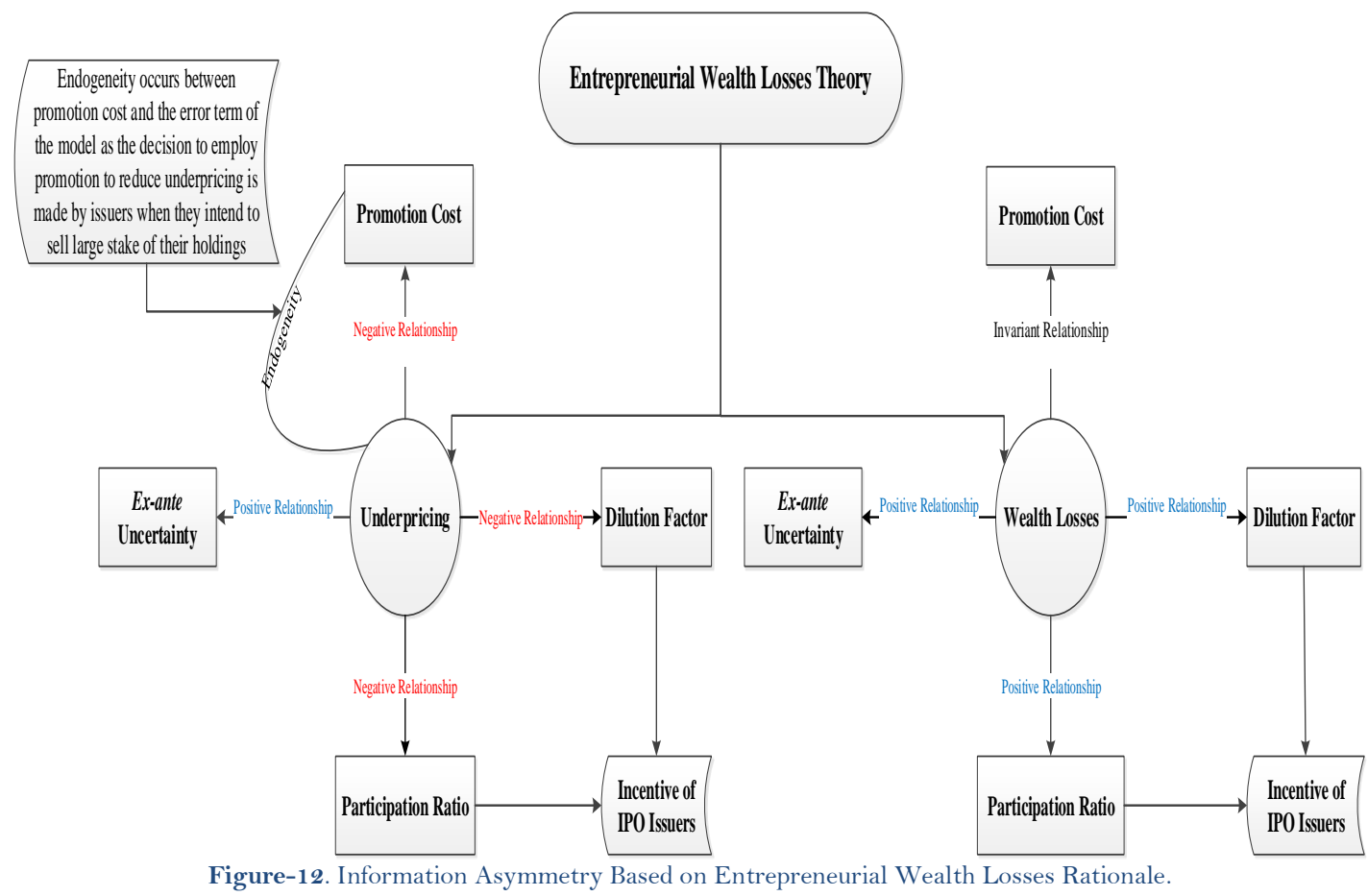

The two testable hypotheses explain underpricing and wealth losses of IPO firms based on three dimensions: incentive of IPO issuers, promotion costs, and uncertainty surrounding the offering as shown in Figure 12:

The first hypothesis, i.e. underpricing hypothesis, argues that underpricing decreases in line with promotion costs, participation ratio, and dilution factor while underpricing increases in uncertainty when controlling for promotion costs. 
The second hypothesis, i.e. wealth losses hypothesis, argues wealth losses increase in line with the participation ratio, the dilution factor, and uncertainty, but are invariant to promotion costs. For both hypotheses, promotion costs increase in line with the participation ratio, the dilution factor, and uncertainty.

Since the introduction of Habib and Ljungqvist (2001) theory, endogeneity correction model, and empirical results, number of researchers focused on examining the validity of the EWL theory in explaining the phenomenon of IPO underpricing. The central aim of this school of thought directed towards testing the endogenous nature of the relationship between underwriter reputation and underpricing in the IPO market which is an important dimension of the EWL model. For example, Ljungqvist and Wilhelm (2003) find some support for the prediction of the EWL theory employing 2,178 listed IPO firms in the U.S. market between January 1996 and December 2000, specifically in relation to explaining the underpricing of technology IPO firms. The authors document significant evidence showing that underpricing is higher for technology compared to non-technology firms because IPO issuers of the former sell and create fewer secondary and primary shares, and there are less participation ratio and dilution factor when they go public, respectively. The authors also find that when IPO issuers intend to sell fewer secondary shares, they show less care about underpricing and for this reason they employ less reputable underwriters who charger cheaper underwriting fees. They also find that when the ex-ante uncertainty of the technology firm is high proxied by a small size of the IPO firm, underpricing tends to be higher. Ljungqvist and Wilhelm (2003) document that when they treated underwriter reputation as an exogenous factor using an OLS estimation, they find a positive and significant coefficient between underwriter reputation and underpricing. However, after applying an endogeneity correction model using a 2SLS model with a robust instrument variable following Habib and Ljungqvist (2001) the authors find a significant and negative coefficient between prestigious underwriters and underpricing.

Kennedy et al. (2006) examine the relative importance of six asymmetric information models in explaining the puzzling phenomenon of IPO underpricing of 2,381 IPO firms listed in the U.S. IPO market between 1991 and 1998. The authors discover that the EWL theory offers the most compelling explanation for IPO underpricing in that country's IPO market. The authors also document a significant change in the underwriter reputation-underpricing relationship from positive to negative after applying the endogeneity correction method proposed by Habib and Ljungqvist (2001). Fang (2005) also cautions for not accounting for the endogenous choice between the issuer-underwriter matching in the bond market using 3,000 corporate nonconvertible bonds issued between January 1991 and December 2000 in the U.S. market. The authors apply the endogeneity correction procedure proposed by Habib and Ljungqvist (2001) finding that reputable underwriters charge higher underwriting fees in exchange for lower yields leading to higher net proceeds for bond issuers. Similar evidence also documented by Mantecon and Poon (2009) and Akkus, Cookson, and Hortaçsu (2016) show that the positive relationship between underwriter reputation and underpricing found in the 1990 s by previous studies disappears. This occurs after controlling for the endogenous choice of IPO issuers in selecting reputable underwriters when they intend to sell large portions of their holdings which changed to negative in the U.S. IPO market.

\section{Institutional Explanations}

The consideration of institutional explanations for IPO underpricing in the U.S. stock market has inspired the emergence of three dominant institutional-based theories, including lawsuit avoidance, price stabilization, and tax advantages hypotheses.

\subsection{Lawsuit Avoidance}

The existence of litigious characteristics of American investors has motivated the emergence of the lawsuit avoidance hypothesis. The likelihood of a linkage between IPO underpricing and litigation risk goes back to Logue (1973) and Ibbotson (1975) who propose that U.S. IPO issuers deliberately underprice the value of their firms at the time of offering to avoid potential litigation risk from disappointed investors due to poor post-IPO performance. That is, the consequence of a lawsuit not only directly inflicts damages on the defendants including financial damages resulting from incurred legal fees and diversion of management time, it also extends to indirect damage including loss of reputation, capital and the likelihood of incurring higher costs of raising capital in the future (Jenkinson \& Ljungqvist, 2001). This lawsuit avoidance rationale is further extended and theoretically modeled by other researchers including Tinic (1988), Hughes and Thakor (1992) and Hensler (1995). The empirical validity of the lawsuit avoidance hypothesis is tested by Lowry and Shu (2002) showing that approximately six percent of IPO firms in the U.S. were sued, with damages to plaintiffs averaging $13.3 \%$ of the proceeds of IPOs from 1988 and 1995.

The empirical validity of the lawsuit avoidance hypothesis is questioned by the contention that it is a U.S.centric model, while the phenomenon of IPOs underpricing is global. This argument implies that the existence of a litigious culture among American investors may not exist in global settings, so this theoretical explanation may fail to explain underpricing around the world. Empirical evidence refuting the litigious effect of the lawsuit avoidance hypothesis on explaining IPO underpricing shows the absence this hypothesis having any economic significance in the U.K. (Jenkinsonn, 1990) Japan (Beller, Terai, \& Levine, 1992), Finland 
(Keloharju, 1993) Switzerland (Kunz \& Aggarwal, 1994) Sweden (Loughran et al., 1994) and Australia (Lee et al., 1996).

\subsection{Price Stabilization}

The price stabilization hypothesis arises as a second institutional explanation of IPO underpricing. The basic notion of this hypothesis relates to the price support service that IPO underwriters offer in relation to post-IPO price stabilization, whereby underwriters intervene in the aftermarket to reduce potential price drops for a few days or weeks. The theoretical concept of price stabilization was originally devised by Booth and Smith (1986) formalized by Benveniste, Busaba, and Wilhelm (1996) and proved its statistical validity in the U.S. market due to the empirical work carried out by Ruud (1993) and Ellis, Michaely, and O'hara (2000). However, the price stabilization rationale is criticized for being unobservable by investors, although it can be observed by market regulators. In other words, it is difficult to empirically know which IPO firms receive price support by underwriters and the magnitude and nature of this support is unknown to market participants (Jenkinson \& Ljungqvist, 2001). The lack of availability of such an exclusive dataset makes it a challenging task to examine the validity of the price stabilization hypothesis, especially in cross-country settings.

\subsection{Tax Argument}

The third institutional-based explanation for IPO underpricing is inspired by the trade-off between tax benefits and underpricing of IPO firms. Rydqvist (1997) empirically explores this tax benefit-based rationale in the Swedish IPO market and finds that before 1990, the Swedish tax system imposed a higher tax rate on employment income than capital gains. This created an inducement to pay employees by allocating appreciating assets in exchange for wages, and the offering of underpriced shares was a form of appreciating assets. Once the Swedish tax system was changed in 1990 to remove the higher tax on underpricing-related gains, thus removing management inducement to allocate underpriced shares to employees, the degree of IPO underpricing dropped from $41 \%$ in 1980-1989 to eight percent in 1990-1994. Similar evidence was documented in the U.S. IPO market by Guenther and Willenborg (1999) and Taranto (2003). However, this tax benefits argument for underpricing may not be useful in explaining the high degree of IPO underpricing observed in tax-free countries, such as the oil- and gas-rich countries 2 where average IPO underpricing is around 250.17\%, making the tax hypothesis questionable (Uddin \& Raj, 2012).

\section{Ownership and Control Reasons}

Ownership and control theories contend that IPO underpricing works as an effective mechanism in shaping the shareholder base in order to deter outside investors from intervening in managing their firms once they are publicly listed. In addition, the existence of the agency problem due to the separation of ownership and control means that misalignment could exist between managing and non-managing shareholders (Jensen \& Meckling, 1976). The outcome, for example, of this misalignment is that managers can exploit their controlling authority to maximize their expected private benefits at the expense of outside shareholders. Based on the above rationale, two main hypotheses emerged to explain the underpricing phenomenon, namely, the entrenchment of managerial control and agency costs hypotheses.

\subsection{Entrenchment Managerial Control}

The entrenchment of managerial control hypothesis is that owners or managers of IPO firms employ underpricing as a tool to maximize their control over the management of their firms by ensuring greater ownership dispersion (Shleifer \& Vishny, 1989). This hypothesis is empirically examined by Brennan and Franks (1997) who conclude that managers of U.K. IPO firms protect their private benefits by strategically allocating underpriced shares to small outside investors. The authors interpret this opportunistic behavior as a strategy those managers tactically adopt when they fear the consequence of close internal monitoring resulting from involving large block investors in the decision-making of their firms. That is, the presence of a widely fragmented post-IPO ownership offers reduced external monitoring, allowing insiders, such as managing owners and managers to have entrenched control over the company's management (Booth \& Chua, 1996). Therefore, underpricing works to create excess demand enabling self-driven managers to ration share allocation in order to ensure wider ownership dispersion, leading to greater control of management operations.

Although the validity of the entrenchment of managerial control hypothesis has been empirically proven by Pagano and Panetta (1998) it has been criticized for not being an efficient way to protect private benefits of control. Engelen and Van Essen (2010) argue against the managerial control explanation. They contend that this mechanism might provide a rational elucidation for underpricing in the U.K. and U.S., but not in many continental European and developing countries as IPO issuers in those nations normally sell a small portion of their secondary shares after going public, hence they need not underprice to retain control over the firm.

2 Underpricing figure is average underpricing for the six Arabian Gulf countries, i.e. Saudi Arabia, United Arab Emirates (UAE), Kuwait, Qatar, Bahrain, and Oman. 
Khurshed and Chahine (2007) provided support for the argument raised by Engelen and Van Essen (2010) i.e. the rationale of the managerial control explanation weakly explains whether block-holder ownership verifies the difference between family and non-family IPOs in France. Moreover, Wang (2005) rejected the rationale of the managerial control hypothesis in explaining IPO underpricing in China.

Authors criticized the managerial control explanation for not being an efficient way to protect private benefits of control. For example, Field and Karpoff (2002) argue that instead of ensuring fragmented post-IPO ownership through the offering of underpriced shares, IPO firms can protect their private benefit of control by issuing non-voting shares when they go public.

Conceptually, if the degree of underpricing of IPOs with voting shares is higher than IPOs with nonvoting shares then it can be said that the managerial control hypothesis is a good theoretical candidate to explain the phenomenon of IPO underpricing (Jenkinson \& Ljungqvist, 2001). Smart and Zutter (2003) empirically find the degree of underpricing of U.S. IPO firms that issue voting shares is higher than IPO firms that issue non-voting stocks. Field and Sheehan (2004) empirically detect no significant relationship between IPO underpricing and the creation of post-IPO shareholding domination.

Finally, the managerial control hypothesis treats the employment of reputable underwriters by the issuers of IPO firms as an exogenous decision ignoring the choice of the underwriter as decided by the issuers. This happens when issuers intend to sell part of their holding before going public, and ignoring this endogeneity leads to omitted variable bias as argued by Habib and Ljungqvist (2001), Chen and Mohan (2002), Chahine (2008); Mantecon and Poon (2009) and Jones and Swaleheen (2010). In this way, the validity of the entrenchment managerial control hypothesis is questionable.

\subsection{Agency Costs}

The prediction of the agency costs hypothesis is contrary to the prediction of the entrenchment of managerial control hypothesis of IPO underpricing proposed by Brennan and Franks (1997). The agency costs hypothesis proposes that due to a separation of ownership and control, misalignment might exist between non-managing shareholders and managers.

Thus, Stoughton and Zechner (1998) argue that owners of IPO firms underprice their firms when they go public, aiming to attract large block-holders who might work as an internal monitoring agent of their firms to minimize agency problems between managers and shareholders. This, in turn, leads to maximizing the value of their firms post-offering. However, Field and Sheehan (2004) empirically find no supporting evidence of the relationship between IPO underpricing and the creation of post-IPO shareholding, thus questioning the rationale of the agency costs hypothesis.

\section{Behavioral Explanation}

Ljungqvist (2007) argues that the substantial amount of money left on the table by U.S. IPO issuers accounted for approximately $\$ 62$ billion in 1999 and 2000, and that such substantial losses of issuer wealth has induced researchers to turn to behavioral explanations for IPO underpricing. In this section, the presence of informational cascades as a behavioral explanation is discussed where the central argument is that the IPO market is prone to the presence of 'irrational' investors who bid up the price of IPO shares beyond their true value.

\subsection{Informational Cascades}

Welch (1992) develops a model showing that 'informational cascades' can occur amongst IPO investors in an attempt to explain the presence of IPO underpricing based on the irrational investor argument. The author contends that IPO investors formulate their investment actions sequentially, whereby the bids of later investors are conditioned on the bids of earlier investors, irrationally ignoring their own information. When latter investors observe the presence of a number of successful initial sales by earlier investors, then later investors reach an understanding that earlier investors possess some form of favorable information. Subsequently, later investors disregard their own information and invest in whatever earlier investors invest in (Jegadeesh, Weinstein, \& Welch, 1993).

In contrast, when later investors observe the presence of a number of unsuccessful initial sales by earlier investors, then later investors withdraw their intention to invest irrespective of their own information. Due to the presence of this irrational investment behavior, demand can be either low or, alternatively, snowballs over time (Pollock, Rindova, \& Maggitti, 2008).

Welch (1992) argues that the likelihood of cascades provides early investors with the power to 'demand' further underpricing in order to commit to purchasing IPO shares, thus ensuring continuity of a positive cascade. Hence, the presence of informational cascades among IPO investors can explain IPO underpricing. However, the possibility of empirically examining the presence of informational cascades among IPO investors requires the availability of exclusive information that shows bid patterns of IPO shares on the first trading day, something that might only be available in advanced countries where sophisticated and transparent trading systems are available. 
However, the empirical validity of the informational cascades hypothesis is proven amongst Israeli IPO investors (Amihud, Hauser, \& Kirsh, 2003) and also amongst U.S. IPO investors (Pollock et al., 2008). However, employing the informational cascades hypothesis to explain differences in IPO underpricing across stock markets may be difficult due to the unavailability of exclusive information that shows the bid patterns of IPO shares on the first trading day in cross-country settings.

\section{Conclusion}

The purpose of this paper was to provide succinct but relatively sufficient review of competing for IPO underpricing theories. The authors recognized a lack of availability for theoretical explanations of the phenomenon of IPO underpricing in the literature. This indeed left researchers and investors in the dark when it comes to deciding on which model to employ to understand why IPO issuers folate their firms at a discount? This paper presented a discussion to explain the motivation of IPO issuers to go public followed by a presentation of the role of key parties in the IPO process. Subsequently, the authors provided a discussion of 13 theoretical models based on information asymmetry, institutional explanations, ownership and control reasons, and behavioral explanations to explain the phenomenon of IPO underpricing.

Based on this review, the authors argued that the underpricing phenomenon is ultimately explained by the existence of asymmetric information in the IPO market. The paper contended that asymmetric information models are considered to be well-established and modeled theories compared to other non-information asymmetry-based models. In particular, this paper favored the Entrepreneurial Wealth Losses (EWL) theory developed by Habib and Ljungqvist (2001). This is because the theoretical explanation offered by the EWL model is the only one that solves the problem of information asymmetry between the issuer and investor, while accounting for the endogenous relationship between underwriter reputation and IPO underpricing.

\section{References}

Affleck-Graves, J., Hegde, S. P., Miller, R. E., \& Reilly, F. K. (1993). The effect of the trading system on the underpricing of initial public offerings. Financial Management, 22(1), 99-108.

Akkus, O., Cookson, J. A., \& Hortaçsu, A. (2016). Assortative matching and reputation in the market for first issues. University of Colorado at Boulder, Working Paper No. 1-48.

Allen, F., \& Faulhaber, G. R. (1989). Signalling by underpricing in the IPO market. Journal of Financial Economics, 23(2), 303-323.

Amihud, Y., Hauser, S., \& Kirsh, A. (2003). Allocations, adverse selection, and cascades in IPOs: Evidence from the Tel Aviv stock exchange. Journal of Financial Economics, 68(1), 137-158.

Autore, D., Smart, S. B., Boulton, T. J., \& Zutter, C. J. (2014). The impact of institutional quality on initial public offerings. Journal of Economics and Business, 73(1), 65-96.

Ball, R., Robin, A., \& Wu, J. S. (2003). Incentives versus standards: Properties of accounting income in four East Asian countries. Journal of Accounting and Economics, 36(1), 235-270.

Banerjee, S., Dai, L., \& Shrestha, K. (2011). Cross-country IPOs: What explains differences in underpricing? Journal of Corporate Finance, $17(5), 1289-1305$

Banu, D. M. (2002). The relationship between IPO returns and factors influencing IPO performance: Case of Istanbul stock Exchange. Managerial Finance, 28(2), 18-38.

Baron, D. P. (1982). A model of the demand for investment banking advising and distribution services for new issues. The Journal of Finance, 37(4), 955-976.

Baron, D. P., \& Holmström, B. (1980). The investment banking contract for new issues under asymmetric information: Delegation and the incentive problem. The Journal of Finance, 35(5), 1115-1138.

Beatty, R. P., \& Ritter, J. R. (1986). Investment banking, reputation, and the underpricing of initial public offerings. Journal of Financial Economics, 15(1), 2 13-232.

Beatty, R. P., \& Welch, I. (1996). Issuer expenses and legal liability in initial public offerings. The Journal of Law and Economics, 39(2), 545-602.

Beller, A. L., Terai, T., \& Levine, R. M. (1992). Looks can be deceiving: A comparison of initial public offering procedures under Japanese and US securities laws. Law and Contemporary Problems, 55(4), 77-118.

Benveniste, L. M., Busaba, W. Y., \& Wilhelm, W. J. (1996). Price stabilization as a bonding mechanism in new equity issues. Journal of Financial Economics, 42(2), 223-255.

Benveniste, L. M., \& Spindt, P. A. (1989). How investment bankers determine the offer price and allocation of new issues. Journal of Financial Economics, 24(2), 343-36 1.

Benveniste, L. M., \& Wilhelm, W. J. (1990). A comparative analysis of IPO proceeds under alternative regulatory environments. Journal of Financial Economics, 28(1), 173-207.

Berglöf, E., \& Pajuste, A. (2005). What do firms disclose and why? Enforcing corporate governance and transparency in Central and Eastern Europe. Oxford Review of Economic Policy, 21(2), 178-197.

Booth, J. R., \& Chua, L. (1996). Ownership dispersion, costly information, and IPO underpricing. Journal of Financial Economics, 41(2), 291-310.

Booth, J. R., \& Smith, R. L. (1986). Capital raising, underwriting and the certification hypothesis. Journal of Financial Economics, 15(1), 261-281.

Brau, J. C., \& Fawcett, S. E. (2006). Initial public offerings: An analysis of theory and practice. The Journal of Finance, 61(1), 399-436.

Brennan, M. J., \& Franks, J. (1997). Underpricing, ownership and control in initial public offerings of equity securities in the UK. Journal of Financial Economics, 45(3), 391-413. 
Carter, R. B., Dark, F. H., \& Singh, A. K. (1998). Underwriter reputation, initial returns, and the long-run performance of IPO stocks. The Journal of Finance, 53(1), 285-311.

Carters, R., \& Manaster, S. (1990). Initial public offerings and underwriter reputation. The Journal of Finance, 45(4), 10451067.

Chahine, S. (2008). Underpricing versus gross spread: New evidence on the effect of sold shares at the time of IPOs. Journal of Multinational Financial Management, 18(2), 180-196.

Chen, C. R., \& Mohan, N. J. (2002). Underwriter spread, underwriter reputation, and IPO underpricing: A simultaneous equation analysis. Journal of Business Finance \& Accounting, 29(3-4), 52 1-540.

Chenn, A., \& Kao, L. (2006). The benefit of excluding institutional investors from fixed-price IPOs: Evidence from Taiwan. Emerging Markets Finance and Trade, 42(6), 5-24.

Chishty, M. R., Hasan, I., \& Smith, S. D. (1996). A note on underwriter competition and initial public offerings. Journal of Business Finance \& Accounting, 23(5-6), 905-914.

Cornelli, F., Goldreich, D., \& Ljungqvist, A. (2006). Investor sentiment and pre-IPO markets. The Journal of Finance, 61(3), 1187-1216.

Daily, C. M., Certo, S. T., Dalton, D. R., \& Roengpitya, R. (2003). IPO underpricing: A meta-analysis and research synthesis. Entrepreneurship Theory and Practice, 27(3), 271-295.

Darmadi, S., \& Gunawan, R. (2013). Underpricing, board structure, and ownership: An empirical examination of Indonesian IPO firms. Managerial Finance, 39(2), 181-200.

Degeorge, F., Derrien, F., \& Womack, K. L. (2007). Analyst hype in IPOs: Explaining the popularity of bookbuilding. The Review of Financial Studies, 20(4), $1021-1058$.

Demers, E., \& Lewellen, K. (2003). The marketing role of IPOs: Evidence from internet stocks. Journal of Financial Economics, 68(3), 413-437.

Dolvin, S. D., \& Jordan, B. D. (2008). Underpricing, overhang, and the cost of going public to preexisting shareholders. Journal of Business Finance \& Accounting, 35(3-4), 434-458.

Dorn, D. (2009). Does sentiment drive the retail demand for IPOs? Journal of Financial and Quantitative Analysis, 44(1), 85108.

Ellis, K., Michaely, R., \& O'hara, M. (2000). When the underwriter is the market maker: An examination of trading in the IPO aftermarket. The Journal of Finance, 55(3), 1039-1074.

Engelen, P.-J., \& Van Essen, M. (2010). Underpricing of IPOs: Firm-, issue-and country-specific characteristics. Journal of Banking \& Finance, 34(8), 1958-1969.

Espenlaub, S., \& Tonks, I. (1998). Post-IPO directors' sales and reissuing activity: An empirical test of IPO signalling models. Journal of Business Finance \& Accounting, 25(9-10), 1037-1079.

Fan, J. P., Wong, T. J., \& Zhang, T. (2007). Politically connected CEOs, corporate governance, and Post-IPO performance of China's newly partially privatized firms. Journal of Financial Economics, 84(2), 330-357.

Fang, L. H. (2005). Investment bank reputation and the price and quality of underwriting services. The Journal of Finance, $60(6), 2729-2761$

Field, L. C., \& Karpoff, J. M. (2002). Takeover defenses of IPO firms. The Journal of Finance, 57(5), 1857-1889.

Field, L. C., \& Sheehan, D. P. (2004). IPO underpricing and outside blockholdings. Journal of Corporate Finance, 10(2), 263280.

Fitza, M., \& Dean, T. J. (2016). How much do VCS and underwriters matter? A comparative investigation of venture capitalist and underwriter effects on IPO underpricing. Venture Capital, 18(2), 95-114.

Gale, I., \& Stiglitz, J. E. (1989). The informational content of initial public offerings. The Journal of Finance, 44(2), 469-477.

Garfinkel, J. A. (1993). IPO underpricing, insider selling and subsequent equity offerings: Is underpricing a signal of quality? Financial Management, 22(1), 74-83.

Grinblatt, M., \& Hwang, C. Y. (1989). Signalling and the pricing of new issues. The Journal of Finance, 44(2), 393-420.

Guenther, D. A., \& Willenborg, M. (1999). Capital gains tax rates and the cost of capital for small business: Evidence from the IPO market. Journal of Financial Economics, 53(3), 385-408.

Habib, M. A., \& Ljungqvist, A. P. (2001). Underpricing and entrepreneurial wealth losses in IPOs: Theory and evidence. The Review of Financial Studies, $14(2), 433-458$.

Hamao, Y., Packer, F., \& Ritter, J. R. (2000). Institutional affiliation and the role of venture capital: Evidence from initial public offerings in Japan. Pacific-Basin Finance Journal, 8(5), 529-558.

Hensler, D. A. (1995). Litigation costs and the underpricing of initial public offerings. Managerial and Decision Economics, 16(2), $111-128$.

Hopp, C., \& Dreher, A. (2013). Do differences in institutional and legal environments explain cross-country variations in IPO underpricing? Applied Economics, 45(4), 435-454.

Hughes, P. J., \& Thakor, A. V. (1992). Litigation risk, intermediation, and the underpricing of initial public offerings. The Review of Financial Studies, 5(4), 709-742.

Ibbotson, R. G. (1975). Price performance of common stock new issues. Journal of Financial Economics, 2(3), $235-272$.

Jegadeesh, N., Weinstein, M., \& Welch, I. (1993). An empirical investigation of IPO returns and subsequent equity offerings. Journal of Financial Economics, 34(2), 153-175.

Jenkinson, T., \& Ljungqvist, A. (2001). Going public: The theory and evidence on how companies raise equity finance (2nd ed.). USA, New York: Oxford University Press.

Jenkinsonn, T. J. (1990). Initial public offerings in the United Kingdom, the United States, and Japan. Journal of the Japanese and International Economies, 4(4), 428-449.

Jensen, M. C., \& Meckling, W. H. (1976). Theory of the firm: Managerial behavior, agency costs and ownership structure. Journal of Financial Economics, 3(4), 305-360.

Jones, T. L., \& Swaleheen, M. (2010). Endogenous examination of underwriter reputation and IPO returns. Managerial Finance, 36(4), 284-293. 
Joness, S. L., Megginson, W. L., Nash, R. C., \& Netter, J. M. (1999). Share issue privatizations as financial means to political and economic ends. Journal of Financial Economics, 53(2), 217-253.

Keloharju, M. (1993). The winner's curse, legal liability, and the long-run price performance of initial public offerings in Finland. Journal of Financial Economics, 34(2), 25 1-277.

Kennedy, D. B., Sivakumar, R., \& Vetzal, K. R. (2006). The implications of IPO underpricing for the firm and insiders: Tests of asymmetric information theories. Journal of Empirical Finance, 13(1), 49-78.

Khurshed, A., \& Chahine, S. (2007). Block-holder ownership, family control and post-listing performance of French IPOs. Managerial Finance, 33(6), 388-400.

Kirkulak, B., \& Davis, C. (2005). Underwriter reputation and underpricing: Evidence from the Japanese IPO market. Pacific-Basin Finance Journal, 13(4), 451-470.

Kunz, R. M., \& Aggarwal, R. (1994). Why initial public offerings are underpriced: Evidence from Switzerland. Journal of Banking Eं Finance, 18(4), 705-723.

Kutsuna, K., \& Smith, R. (2003). Why does book building drive out auction methods of IPO issuance? Evidence from Japan. The Review of Financial Studies, 17(4), 1129-1166.

Lam, S.-S., \& Yap, W. (1998). Pricing system and the initial public offerings market: A case of Singapore. International Review of Economics \& Finance, 7(3), 297-313.

Lee, P. J., Taylor, S. L., \& Walter, T. S. (1996). Australian IPO pricing in the short and long run. Journal of Banking $\Theta^{\circ}$ Finance, 20(7), 1189-1210.

Lees, P. M., \& Wahal, S. (2004). Grandstanding, certification and the underpricing of venture capital backed IPOs. Journal of Financial Economics, 73(2), 375-407.

Leleux, B. F., \& Muzyka, D. F. (1997). European IPO markets: The post-issue performance imperative. Entrepreneurship: Theory and Practice, 21(4), 111-119.

Leone, A. J., Rock, S., \& Willenborg, M. (2007). Disclosure of intended use of proceeds and underpricing in initial public offerings. Journal of Accounting Research, 45(1), 111-153.

Lewellen, K. (2006). Risk, reputation, and IPO price support. The Journal of Finance, 61(2), 613-653.

Lin, T. H. (1996). The certification role of large block shareholders in initial public offerings: The case of venture capitalists. Quarterly Journal of Business and Economics, 35(2), 55-65.

Ling, D. C., \& Ryngaert, M. (1997). Valuation uncertainty, institutional involvement, and the underpricing of IPOs: The case of REITs. Journal of Financial Economics, 43(3), 433-456.

Liu, X., \& Ritter, J. R. (2010). The economic consequences of IPO spinning. The Review of Financial Studies, 23(5), 20242059.

Liu, X., \& Ritter, J. R. (2011). Local underwriter oligopolies and IPO underpricing. Journal of Financial Economics, 102(3), $579-601$.

Ljungqvist, A. (2007). IPO underpricing. In BE Eckbo (ed.), Handbook of Corporate Finance: Emprical Corporate Finance (1st ed., pp. 559). The Netherlands: Elsevier B.V.

Ljungqvist, A., \& Wilhelm, J. W. J. (2003). IPO pricing in the dot-com bubble. The Journal of Finance, 58(2), 723-752.

Ljungqvists, A. P., Jenkinson, T., \& Wilhelm, J. W. J. (2003). Global integration in primary equity markets: The role of US banks and US investors. The Review of Financial Studies, 16(1), 63-99.

Logue, D. E. (1973). On the pricing of unseasoned equity issues: 1965-1969. Journal of Financial and Quantitative Analysis, 8(1), 91-103.

Loughran, T., \& Ritter, J. R. (2002). Why don't issuers get upset about leaving money on the table in IPOs? The Review of Financial Studies, $15(2)$, 413-444.

Loughran, T., \& Ritter, J. R. (2004). Why has IPO underpricing changed over time? Financial Management, 33(3), 5-37.

Loughran, T., Ritter, J. R., \& Rydqvist, K. (1994). Initial public offerings: International insights. Pacific-Basin Finance Journal, 2(2-3), 165-199.

Lowry, M., \& Shu, S. (2002). Litigation risk and IPO underpricing. Journal of Financial Economics, 65(3), 309-335.

Mantecon, T., \& Poon, P. (2009). An analysis of the liquidity benefits provided by secondary markets. Journal of Banking \& Finance, 33(2), 335-346.

Marisetty, V. B., \& Subrahmanyam, M. G. (2010). Group affiliation and the performance of IPOs in the Indian stock market. Journal of Financial Markets, 13(1), 196-223.

Megginson, W. L., \& Weiss, K. A. (1991). Venture capitalist certification in initial public offerings. The Journal of Finance, 46(3), 879-903.

Michaely, R., \& Shaw, W. H. (1994). The pricing of initial public offerings: Tests of adverse-selection and signaling theories. The Review of Financial Studies, 7(2), 279-319.

Mok, H. M., \& Hui, Y. (1998). Underpricing and aftermarket performance of IPOs in Shanghai, China. Pacific-Basin Finance Journal, 6(5), 453-474.

Muscarella, C. J., \& Vetsuypens, M. R. (1989). A simple test of Baron's model of IPO underpricing. Journal of Financial Economics, 24(1), 125-135.

Pagano, M., \& Panetta, F. (1998). Why do companies go public? An empirical analysis. The Journal of Finance, 53(1), $27-64$.

Palmiter, A. R. (1999). Toward disclosure choice in securities offerings. Columbia Business Law Revier, 1(1), 86-91.

Pollock, T. G., Rindova, V. P., \& Maggitti, P. G. (2008). Market watch: Information and availability cascades among the media and investors in the US IPO market. Academy of Management Journal, 51(2), 335-358.

Rasheed, A. M., Datta, D. K., \& Chinta, R. R. (1997). Determinants of price premiums: A study of initial public offerings in the medical diagnostics and devices industry. Journal of Small Business Management, 35(4), 11-23.

Ritter, J. (1984). The" hot issue" market of 1980. The Journal of Business, 57(2), 215-240.

Ritter, J. (2008). Initial public offerings: Underpricing, University of Florida. Retrieved from https://site.warrington.ufl.edu/ritter/files/2018/07/IPOs2017Underpricing.pdf.

Ritter, J. (2011). Equilibrium in the initial public offerings market. Annual Review of Financial Economics, 3(1), 347-374. 
Ritterr, J. R. (1987). The costs of going public. Journal of Financial Economics, 19(2), 269-281.

Ritters, J. R., \& Welch, I. (2002). A review of IPO activity, pricing, and allocations. The Journal of Finance, 57(4), 17951828.

Rock, K. (1986). Why new issues are underpriced. Journal of Financial Economics, 15(1), 187-2 12.

Ruud, J. S. (1993). Underwriter price support and the IPO underpricing puzzle. Journal of Financial Economics, 34(2), 135151.

Rydqvist, K. (1997). IPO underpricing as tax-efficient compensation. Journal of Banking \& Finance, 21(3), 295-313.

Shleifer, A., \& Vishny, R. W. (1989). Management entrenchment: The case of manager-specific investments. Journal of Financial Economics, 25(1), 123-139.

Smart, S. B., \& Zutter, C. J. (2003). Control as a motivation for underpricing: A comparison of dual and single-class IPOs. Journal of Financial Economics, 69(1), 85-110.

Spatt, C., \& Srivastava, S. (1991). Preplay communication, participation restrictions, and efficiency in initial public offerings. The Review of Financial Studies, 4(4), 709-726.

Spiess, K. D., \& Pettway, R. H. (1997). The IPO and first seasoned equity sale: Issue proceeds, owner/managers' wealth, and the underpricing signal. Journal of Banking \& Finance, 21(7), 967-988.

Stoughton, N. M., \& Zechner, J. (1998). IPO-mechanisms, monitoring and ownership structure. Journal of Financial Economics, 49(1), 45-77.

Sullivan, M. J., \& Unite, A. A. (2001). The influence of group affiliation and the underwriting process on emerging market IPOs: The case of the Philippines. Pacific-Basin Finance Journal, 9(5), 487-512.

Taranto, M. A. (2003). Employee stock options and the underpricing of initial public offerings, Working Paper, University of Pennsylvania. Retrieved from http://citeseerx.ist.psu.edu/viewdoc/download?doi=10.1.1.197.3092\&rep=rep 1\&type=pdf.

Tinic, S. M. (1988). Anatomy of initial public offerings of common stock. The Journal of Finance, 43(4), 789-822.

Tomczyk, S. (1996). Auditor reputation and initial public offerings by foreign companies. Journal of International Accounting, Auditing and Taxation, 5(2), 249-262.

Uddin, M., \& Raj, M. (2012). Aftermarket risk and underpricing of initial public offers in the Arabian Gulf countries: An empirical analysis. The International Journal of Business and Finance Research, 6(3), 123-138.

Wang, C. (2005). Ownership and operating performance of Chinese IPOs. Journal of Banking \& Finance, 29(7), 1835-1856.

Welch, I. (1989). Seasoned offerings, imitation costs, and the underpricing of initial public offerings. The Journal of Finance, $44(2), 421-449$.

Welch, I. (1992). Sequential sales, learning, and cascades. The Journal of Finance, 47(2), 695-732. 